\title{
Changing Minds: The Impact of Study Abroad Components on Students' Changes in Their Religious Faith
}

\section{Trevor Poag}

Latin American Studies Program

Jill Sperandio

Lehigh University

\section{Introduction}

Current Landscape of Study Abroad

Universities increasingly prioritize intercultural learning experiences that prepare students to become competent professionals in an interconnected world (Egron-Polak, 2012; de Witt, 2009). Study abroad represents one such learning experience for U.S. university students. Study abroad programs, although varied in structure and curriculum, share the common characteristic of connecting students to new cultural and educational experiences. Such intercultural learning presents students with opportunities to critically examine and possibly change their perspectives on important issues.

The number of U.S. study abroad participants more than tripled between 1991 and 2013, with 289,408 students studying abroad during the 2012/13 academic year (Institute for International Education, 2014). The popularity of study abroad has influenced a diversification of program models (McMurtrie, 2009). Participation in short-term programs (eight weeks or less in duration) has increased, while a smaller percentage of students participate in semester or year-length programs (Institute for International Education, 2014). Additional differences among programs models are reflected in student housing (hotel/dormitory vs. host family), language used in coursework (English vs. target language), and academic content (prioritization of U.S. perspectives vs. those of host region). Thus, study abroad describes a diversity of learning experiences that contain substantive differences in structure and curriculum.

The diverse landscape of study abroad challenges educational leaders to exercise precise analysis as they design, evaluate, and research study abroad programming. Speaking to this challenge, Engle and Engle (2003) identified the tendency of scholars and practitioners to group study abroad programs rather than distinguish them by their unique characteristics. They highlighted the benefits of carefully defining the study abroad experience. Engle and Engle argued that efforts to analyze data related to study abroad outcomes are weakened if "we have no precise language to differentiate or categorize the types of study abroad associated with that data" (p.1).

In response to this problem, Engle and Engle (2003) created a level-based, hierarchical classification of study abroad program types. This classification system highlights the diversity among study abroad programs and provides a means to organize and evaluate such programming. In Engle and Engle's view, the ability to facilitate meaningful interaction with the host culture is what most distinguished one program type from another. They identified seven program components, such as student housing and program duration, that inform the categorization of study abroad experiences into one of five program types. Table 1 illustrates how the five program levels correspond to the seven study abroad components. We used Engle and Engle's classification system to define the study abroad 
program in this study, the Latin American Studies Program.

The body of study abroad literature confirms Engle and Engle's (2003) concerns about researchers' tendencies to view study abroad as a uniform experience. Our analysis of this research revealed numerous studies that explored the relationship between study abroad and students' development of second languages (Freed, 1995; Kinginger, 2004), intercultural competencies (Deardorff, 2006; Williams, 2005), global mindedness (Golay, 2006; Kehl, 2006), and personal growth (Black \& Duhon, 2006; Dwyer \& Peters, 2004). Although such research provided empirical evidence of study abroad's impact on participants' development, few studies identified the characteristics of the study abroad programs that influenced such learning. In response to this persistent gap in the literature, we used Gardner's (2006) framework of mind change to identify the specific study abroad components that drove transformative learning in students at the Latin American Studies Program.

Table 1, Engle and Engle's (2003) Study Abroad Program Levels (p.10)

\begin{tabular}{|c|c|c|c|c|c|}
\hline $\begin{array}{l}\text { Program } \\
\text { Components }\end{array}$ & $\begin{array}{l}\text { Level One: } \\
\text { Study Tour }\end{array}$ & $\begin{array}{l}\text { Level Two: } \\
\text { Short-Term Study }\end{array}$ & $\begin{array}{l}\text { Level Three: } \\
\text { Cross-Cultural } \\
\text { Contact Program }\end{array}$ & $\begin{array}{l}\text { Level Four: } \\
\text { Cross-Cultural } \\
\text { Encounter } \\
\text { Program }\end{array}$ & $\begin{array}{l}\text { Level Five: } \\
\text { Cross-Cultural Immersion } \\
\text { Program }\end{array}$ \\
\hline Duration & $\begin{array}{l}\text { Several days } \\
\text { to a few } \\
\text { weeks }\end{array}$ & 3 to 8 weeks & Semester & $\begin{array}{l}\text { Semester to } \\
\text { academic year }\end{array}$ & Semester to academic year \\
\hline $\begin{array}{l}\text { Entry target- } \\
\text { language } \\
\text { competence }\end{array}$ & $\begin{array}{l}\text { Elementary } \\
\text { to } \\
\text { intermediate }\end{array}$ & $\begin{array}{l}\text { Elementary to } \\
\text { intermediate }\end{array}$ & $\begin{array}{l}\text { Elementary to } \\
\text { intermediate }\end{array}$ & $\begin{array}{l}\text { Pre-advanced to } \\
\text { advanced }\end{array}$ & Advanced \\
\hline $\begin{array}{l}\text { Language } \\
\text { used in } \\
\text { course work }\end{array}$ & English & $\begin{array}{l}\text { English and } \\
\text { target-language }\end{array}$ & $\begin{array}{l}\text { English and } \\
\text { target-language }\end{array}$ & $\begin{array}{l}\text { Predominately } \\
\text { target language }\end{array}$ & $\begin{array}{l}\text { Target-language in all } \\
\text { curricular and } \\
\text { extracurricular activities }\end{array}$ \\
\hline $\begin{array}{l}\text { Academic } \\
\text { work context }\end{array}$ & $\begin{array}{l}\text { Home } \\
\text { institution } \\
\text { faculty }\end{array}$ & $\begin{array}{l}\text { In-house or } \\
\text { institute for } \\
\text { foreign students }\end{array}$ & $\begin{array}{l}\text { Student group or } \\
\text { with other } \\
\text { international } \\
\text { students }\end{array}$ & $\begin{array}{l}\text { In house student } \\
\text { group }\end{array}$ & $\begin{array}{l}\text { Local norms, partial or } \\
\text { complete direct enrollment }\end{array}$ \\
\hline Housing & Collective & $\begin{array}{l}\text { Collective and/or } \\
\text { home stay }\end{array}$ & $\begin{array}{l}\text { Collective, home } \\
\text { stay visit, home } \\
\text { stay rental }\end{array}$ & $\begin{array}{l}\text { Home stay rental } \\
\text { or integration } \\
\text { home stay }\end{array}$ & $\begin{array}{l}\text { Individual integration home } \\
\text { stay }\end{array}$ \\
\hline $\begin{array}{l}\text { Provision for } \\
\text { cultural } \\
\text { interaction, } \\
\text { experiential } \\
\text { learning }\end{array}$ & None & None & None or limited & $\begin{array}{l}\text { Optional } \\
\text { participation in } \\
\text { occasional } \\
\text { integration } \\
\text { activities }\end{array}$ & $\begin{array}{l}\text { Required regular } \\
\text { participation in cultural } \\
\text { integration program, } \\
\text { extensive direct cultural } \\
\text { contact via service learning, } \\
\text { work internship }\end{array}$ \\
\hline $\begin{array}{l}\text { Guided } \\
\text { reflection on } \\
\text { cultural } \\
\text { experience }\end{array}$ & None & $\begin{array}{l}\text { Orientation } \\
\text { program }\end{array}$ & $\begin{array}{l}\text { Orientation } \\
\text { program }\end{array}$ & $\begin{array}{l}\text { Orientation } \\
\text { program, initial } \\
\text { and ongoing }\end{array}$ & $\begin{array}{l}\text { Orientation, mentoring, on- } \\
\text { going orientation or course } \\
\text { on culture, reflective writing } \\
\text { and research }\end{array}$ \\
\hline
\end{tabular}




\section{Gardner's (2006) Framework of Mind Change}

Gardner (2006) proposed that mind change occurs when individuals or groups "abandon the way in which they have customarily thought about an issue of importance and henceforth conceive of it in a new way" (p. 2). He referenced examples of mind change in the political, religious, and economic spheres to illustrate the kinds of substantive change that his work addressed. Gardner explained that mind change happens in numerous contexts, ranging from large-scale changes in groups to changes within the mind of an individual.

Gardner (2006) identified seven factors that influence substantive changes of mind. Gardner called these factors levers of change. He proposed that shifts of mind are likely to occur when the seven levers work together to move a group or individual in a new direction. Gardner's seven levers of change are:

1. Reason: Minds can be changed through logical argument.

2. Research: Minds can be changed through data, observations, or case studies.

3. Resonance: Minds can be changed when the mind-to-be-changed resonates with the new content and with the presenter.

4. Representational Redescriptions: Minds can be changed when the new content is presented in a number of different media and symbol systems.

5. Resources and Rewards: Minds can be changed when sufficient rewards (or punishments) are invoked.

6. Real World Events: Minds can be changed when there is a dramatic change in the conditions of the world.

7. Resistances: Minds can be changed when the chief resistances to the desired mind change are neutralized. (p. 12)

In Gardner's words, mind change occurs when "reason (often buttressed with research), reinforcement through multiple forms of representation, real world events, resonance, and resources all push in one direction—and resistances can be identified and successfully countered" (p. 211).

Gardner's (2006) levers of change correspond to the program components in many study abroad models. For example, study abroad students employ the lever of reason when they engage assigned readings (the lever of research) about the contemporary reality of a given host region. Furthermore, when students leave class and engage daily life (lever of real world events) through conversations with their host families and others in the community, they encounter diverse illustrations (representational redescriptions) of the content they explored in class. Table 2 further illustrates the convergence between Gardner's levers of change and study abroad program components.

The correspondence between the levers of change and study abroad program components makes Gardner's framework a relevant lens through which to explore the outcomes of study abroad. If a study abroad program influences students' changes of mind about an important issue, Gardner's framework provides a means to isolate the specific components (levers of change) that influenced this 
change. As such, we chose to use Gardner's framework to explore students' perceptions about changes in their religious faith as related to their study abroad experience at the Latin American Studies Program.

Table 2. Gardner's (2006) Levers of Change Reflected in Study Abroad Components

Levers of Change

Reason

Research

Resonance

Representational Redescriptions

Resources and Rewards

Real World Events

Resistances
Study Abroad Components

Discussion groups, assigned reading material, informal conversations with peers, conversations with program faculty, conversations with host families/friends, lectures/presentations

Student research projects/assignments, lectures, interviews with local experts, assigned readings

Reading/hearing about a topic and then experiencing something that confirms it through a study trip, home stay experience, internship, daily life, or conversation

Engaging content in diverse forms-readings, lectures, practical experiences (home stays, study trips), internship experiences, group discussions, observations of daily life

Grades earned on assignments; positive/negative feedback from hosts, peers, or program faculty; adopting a new perspective to survive in a new context

Experiencing the host reality first hand through home stays and study trips, observing public protests, experiencing natural disasters, observing political processes, second language learning

Resistances to (or support for) a potential change-from family in the U.S., hosts, peers, program faculty

\section{Research Context: The Latin American Studies Program}

The religious character of the Latin American Studies Program (LASP) provides a relevant context in which to explore mind change in the sphere of religious faith. Operating through its headquarters in San José, Costa Rica, LASP extends study abroad programming to member institutions of the Council for Christian Colleges and Universities (CCCU). The CCCU is a consortium of 119 Christian institutions of higher education in North America. Founded in 1976, the CCCU's mission is "to advance the cause of Christ-centered higher education and to help our institutions transform lives by faithfully relating scholarship and service to biblical truth" (Council for Christian Colleges \& Universities, 2015). Thus, CCCU campuses attract Christian students who seek a higher education experience that is grounded in Christian tradition and practice (Patterson, 2001; Railsback, 2006). Member institutions of the CCCU enjoy access to its diverse services, which include political advocacy, professional development, and Christian study abroad programming.

Founded in 1986, LASP is one of ten study abroad programs provided by the CCCU. LASP implements a semester-long learning experience that prioritizes the perspectives of its Latin American hosts in the program's curriculum and structure. While enrolled at LASP, all students complete coursework in Spanish language and Latin American studies, while selecting electives from more concentrated courses in literature, environmental science, and international business. In addition to 
coursework, students live with host families for the duration of the semester, complete an internship experience in a rural community of Costa Rica, and complete study trips to neighboring Latin American countries. As the description below reflects, Engle and Engle's (2003) study abroad classification system defines LASP as approximately a Level Four: Cross-Cultural Encounter Program (see Table 1 for a description of this program level).

LASP courses are facilitated by program faculty, who are from both North America and Latin America. Different from typical courses on a U.S. campus, however, invited speakers from the host community comprise a majority of the lecturers (often in Spanish). Such speakers connect students to diverse Latin American perspectives on course material. The primary role of LASP faculty during coursework is to facilitate meaningful reflection among students on the lectures, assignments, and reading material. Regarding reading material, LASP faculty are purposeful in their selection of literature that presents students with Latin American perspectives on course content. Course assignments also direct students to Latin American voices by incorporating interview components and community-based research.

Additional program components include regular discussion groups and study trips to neighboring Latin American countries. Discussion groups (called process groups at LASP) are small group interactions during which a member of the LASP faculty facilitates integrative reflection on course material and students' experiences in Latin America. Discussion groups occur at least once a week throughout the semester. In addition, LASP implements at least one study trip (often two) to a neighboring Latin American country each semester. Such trips have included two-week learning experiences in Nicaragua, Guatemala, Cuba, and Panama. Study trips include a home stay component, several lectures from local experts, and minimal reading material and assignments. The purpose of study trips is to expose LASP students to the diversity and contrasts that characterize Latin America.

Through their work to implement these components, LASP faculty consistently observe that numerous students each semester articulate changes in their religious faith. When invited to explain such changes, students often identify their study abroad experience with LASP as an important factor in this change. In addition to such conversations with students, LASP faculty observe evidence of students' changes in religious faith in written assignments and course evaluations.

As Gardner (2006) highlighted in his framework of mind change, such changes of mind about religious faith are of "enormous moment" (p. 187). As such, we chose to explore students' perceptions of these changes and the factors that influenced them. The correspondence between Gardner's levers of change and the study abroad components present in LASP facilitated our exploration of students' changes in religious faith (see Table 2).

\section{Research Questions}

Three research questions guided our exploration of LASP students' changes in religious faith:

1. Do LASP alumni perceive their study abroad experience to have influenced a lasting change of mind about their religious faith?

2. When LASP alumni perceive such a change in their religious faith, how do they describe this change and its consequent actions in their communities and the world? 
3. When LASP alumni perceive such a change in their religious faith, to which LASP components do they ascribe this change?

\section{Definitions}

Changes of mind about religious faith: Fowler (1981) described religious faith as an act that involves patterned knowing (belief), patterned valuing (commitment or devotion), and patterned constructions of meaning (often in the form of narratives). Therefore, a change of mind about religious faith is an event characterized by a shift in the way one knows, values, and constructs meaning in the world.

LASP Students: LASP students are undergraduates who major in a diversity of fields. They attend colleges and universities that comprise the Council for Christian Colleges and Universities (CCCU). These CCCU member institutions provide Christian higher education and attract students who seek a higher education experience that is grounded in Christian tradition and practice (Patterson, 2001; Railsback, 2006). As such, most CCCU students are what Smith and Snell (2009) describe as committed traditionalists. Committed traditionalists clearly articulate a strong religious faith, actively practice their faith through regular involvement in a mainstream tradition, and identify faith as a central part of their identity and moral reasoning.

\section{Summary of Method}

\section{Participants and Instrument}

We implemented a qualitative study to collect data related to the research questions. We invited LASP's 1,793 alumni to complete an open-ended, anonymous, and qualitative survey to discern if they identified their study abroad experience with LASP as a contributor to changes in their religious faith (see Appendix A). The survey also invited LASP alumni to describe their perceived change in religious faith and its consequent actions. In addition, the survey asked respondents to identify which LASP components had the most impact on their changes in religious faith. As LASP alumni are geographically dispersed, we conducted the survey online through the Qualtrics program. Qualtrics provides online survey tools for researchers.

\section{Data Analysis}

Through inductive analysis, we categorized each response to the survey prompts. Inductive analysis allows categories to emerge from the data as opposed to using existing frameworks to identify categories (Creswell, 2012). Following our categorization of all data, we identified themes among the categories via tracking back and forth among responses. We selected themes based on their ability to achieve both internal homogeneity and external heterogeneity. Internal homogeneity is the extent to which the data in a given theme hold together, while external homogeneity is the extent to which differences among themes are clear (Patton, 2002). To reduce the possible impact of researcher bias in data analysis, we invited a research assistant to implement expert checks of our interpretation and analysis of the data.

\section{Limitations}

The study contained several limitations: researcher bias, participant self-selection, low survey response rates among earlier LASP cohorts, and its emphasis on the perceptions of respondents. Our proximity to the study's topic presented a risk of researcher bias. As a former LASP faculty member and study broad participant, one researcher brought personal experiences to data analysis that could 
threaten our objectivity. Furthermore, this researcher's experiences abroad as a learner and expat influenced many changes in his religious faith. As such, we analyzed the data with a heightened sense of self-scrutiny to minimize the potential impact of such experiences on our analysis.

An additional limitation of the study was participant self-selection. All survey respondents selfselected as participants in this study. LASP alumni were probably more likely to complete the survey if they perceived their study abroad experience with LASP to have been a positive factor in their personal development. As such, participant self-selection could skew the data in a direction that disproportionately emphasizes students' perceptions that LASP influenced a change in their religious faith.

Low survey response rates among LASP alumni from earlier program cohorts represented another limitation. Alumni from recent cohorts (2000 through 2013) were three times more likely to respond than alumni from earlier cohorts (1986 through 1999). Such low response rates weakened the credibility of comparisons between earlier and more recent LASP cohorts.

Finally, this study's emphasis on participants' perceptions was a limitation. Although we chose to explore perceptions due to the personal nature of changes in religious faith, perceptions are difficult to evaluate and confirm. To minimize this limitation, we asked respondents to describe the nature of their perceived change in religious faith as well as its consequent actions. This served to provide some confirmation of whether respondents' perceptions reflected a substantive change.

\section{Results}

The survey of LASP alumni generated 430 responses, which represent $24 \%$ of LASP's 1,793 alumni. We will organize our presentation of the survey results by relating them to each research question. We will then share results of the document mining of LASP final course evaluations from 2008 through 2013 to triangulate the survey results.

\section{Research Question \#1: Do LASP alumni perceive their study abroad experience to have influenced a lasting change of mind about their religious faith?}

Survey data revealed that $89 \%$ of respondents perceived their study abroad experience with LASP to have influenced a change in their religious faith. Regarding differences in response between alumni from earlier LASP cohorts and those from more recent groups, the data revealed little difference between these groups. LASP alumni from 1986 through 1999 answered "yes" in 87\% of cases, while LASP alumni from 2000 through 2013 answered "yes" 91\% of the time. The 382 respondents who provided an affirmative answer to the first survey prompt were directed to the rest of the survey, while the surveys of the 48 respondents who answered "no" were submitted.

Research Question \#2: When LASP alumni perceive a change in their religious faith, how do they describe this change and its consequent actions in their communities and the world?

Respondents' descriptions of their changes in religious faith revealed four core themes. The four themes are: increased awareness of culture's influence on religious faith, new embrace of doubt, more inclusive religious faith, and greater emphasis on social justice. Table 3 presents a frequency count of 
respondents' descriptions of these changes in religious faith.

Table 3. Frequency Count of Respondents' Descriptions of Their Changes in Religious Faith

\begin{tabular}{ll}
\hline Changes & $n$ \\
& \\
\hline Greater emphasis on social justice & 136 \\
More inclusive religious faith & 133 \\
Increased awareness of culture's influence on religious faith & 91 \\
New embrace of doubt & 71 \\
\hline
\end{tabular}

Increased awareness of culture's influence on religious faith (91 respondents)

The responses of LASP alumni illustrated how their experiences in Latin America awakened them to the influence that culture has on their own and others' religious faith and encouraged them to approach their religious faith through a new cultural framework:

I think the biggest change for me in our LASP experience was moving beyond the 'God Bless America' slogans and the idea that we should be patriots for our country and recognizing that as a follower of Christ I am part of God's kingdom that does not have borders or social classes or value certain people or ways of life more than others. There is nothing wrong with having national pride in our country, but during LASP I began to see ourself as a member of God's Kingdom first and as an American second. (Respondent 320)

Respondents' shared that such realizations about the influence of culture on religion sparked deeper questions and doubts about their previously held religious faith.

New embrace of doubt (71 respondents)

Many respondents expressed that their study abroad experience in Latin America informed the development of a more critical Christian faith. Their responses reflected a new embrace of doubt, questioning, and uncertainty:

Up until the point that I studied abroad, I was taught that Christianity was a cornerstone upon which to base the rest of our life, an 'owner's manual' for how I was supposed to approach the world and the people in it. Studying abroad forced me to turn a critical eye towards everything I'd experienced thus far in our short span of life. . . It taught me to think critically about beliefs I'd taken for granted our whole life (maybe Jesus wasn't white, maybe God doesn't care about who you voted for, maybe gay people aren't going to hell). Most importantly of all, it taught me that it was okay to doubt - maybe even essential. (Respondent 178)

For many respondents, the increased comfort with doubt and questioning allowed their religious faith to become more inclusive.

More inclusive religious faith (133 respondents)

Contact with diverse cultural and economic realities in Latin America encouraged LASP students to loosen the boundaries they had previously constructed around the tenets of their religious faith. A broader, more inclusive concept of God was a common illustration of this change:

Living in the sheltered reality of the U.S. (other than a few one-week missions trips), I had 
very little idea of the realities that the majority of people in the world face in everyday life. As such, our view of God was also limited. I had a first-world God, a God who couldn't identify with poverty, pain and suffering. LASP broadened our view of God, while simultaneously bringing me to the realization that everything I knew about him was just barely scratching the surface of who He is. (Respondent 170)

In addition to developing more inclusive concepts of God, many respondents stated that their interactions with Latin Americans of non-Christian traditions led them to a more accepting religious faith:

Part of what I had believed before LASP was that Christianity and the bible and the Christian God was the ONLY right/true religion and all others were false and their believers were misled. Now, I find that I am able to honor others' beliefs as valid and not judge people or tell them they are wrong, or actively try to convert them and get them to join our religion. ... I came to understand and feel that what I had believed about indigenous faiths before LASP was not the truth - that indigenous people are not 'worshipping Satan;' in fact the indigenous people I stayed with lived out the principles of the gospel of Jesus more holistically and genuinely than any Christian I had encountered. (Respondent 326)

Accompanying this shift to a more inclusive Christian faith, many respondents shared how their study abroad experience in Latin America convinced them of the need to place greater emphasis on social justice as an expression of religious faith.

Greater emphasis on social justice (136 respondents)

Placing greater emphasis on actions that achieve social justice was the most frequent change of religious faith cited by respondents. LASP alumni described a decrease in concern for orthodoxy (right belief) and an increase in concern for orthopraxy (right action). For many respondents, a shift in the way they viewed sacred texts initiated this change:

One of the key changes in our faith that was related to our LASP experience was that I obtained a more justice-oriented faith. After learning how many passages in scripture relate to the poor, the widow, and the disenfranchised, and after seeing poverty that I was unlikely to see in our life in America, our faith became more focused not on the major 'moral issues' on which American Christianity has been so focused, but on literally living out the words of Jesus to love God, love our neighbors, and to serve those in need. (Respondent 100)

By reading the Bible from the margins, I have to see Jesus's life as a prophet who sought justice and not only as a wise teacher who cuddled with children. Seeing the Bible in this way requires action. I cannot say, 'It must be God's will' and sit passively as the world around me needs healing and needs people that are called to action, called to change. (Respondent 205)

The third survey prompt invited respondents to describe actions that emerge from their changes in religious faith. We identified five core themes among the responses to this prompt: justice-centered vocation, creating sustainable economies, transforming communities, family decisions, and personal development. Table 4 presents a frequency count of respondents' actions. 
Table 4. Frequency Count of Actions that Respondents Related to Their Change in Religious Faith

\begin{tabular}{ll}
\hline Actions & $N$ \\
\hline Transforming communities & 148 \\
Justice-centered vocation & 86 \\
Creating sustainable economies & 56 \\
Personal development & 56 \\
Family decisions & 43 \\
\hline
\end{tabular}

Justice-centered vocation (86 respondents)

Respondents' changes in religious faith influenced their vocational paths. In their articulations of the impact that studying abroad had on their vocations, LASP alumni described the justice orientation of their work:

It has led me down the path I follow today as I engage in humanitarian work. It has guided me toward approaches that focus on social justice, and planted the seed of thought that reminds me to prioritize the 'least of these' and highlight vulnerabilities in new ways. I work in women's protection, and what I learned about oppression, vulnerability, and risk during LASP has largely influenced where I direct our professional efforts. (Respondent 56)

Respondents' descriptions of their vocations suggested that they measure career success in the currencies of service and justice, not dollars and euros. In fact, no respondent equated high earnings with vocational success. Instead, respondents' comments on economic matters focused on their actions to achieve sustainable economies.

Creating sustainable economies (56 respondents)

Many respondents stated that they express their changes in religious faith through consumer choices. In respondents' views, their study abroad experience encouraged them to consider the connection among their religious faith, the natural environment, and their economic behavior:

First of all, an environmental consciousness became a huge part of our faith. Following our semester at LASP, stewardship became a huge deal to me. I understood the connection between organics, recycling, fair trade, and what God thinks about all that and why it should matter to me. Shortly after our semester I became a strict vegetarian and have been ever since. This all relates profoundly to our faith because I see it as being a good steward and honoring the things that God has entrusted to us (i.e. the planet, our body). (Respondent 369)

Many respondents' credited their new economic behaviors with strengthening their sense of responsibility to their communities.

Transforming communities (148 respondents)

Involvement in the transformation of communities was the most frequent action that respondents perceived to emerge from their change in religious faith. Such actions included a general increase in community involvement (44/148 respondents), advocacy for the marginalized (42/148 respondents), political activity (22/148 respondents), and donation of money and time (40/148 respondents). The following response reflected one LASP alumnus' general increase in community involvement:

I gained a more global outlook after our study abroad experience, but this also translated 
into becoming more plugged into a local community. I sought out ways to get connected in areas like local community organizations, shelters, education groups. I had a strong desire to live out our faith in ways I had not done so in the past by serving others. (Respondent 71)

Many respondents focused their increased community involvement on advocacy for the marginalized:

It was very influential for me to spend time with all of the low income, marginalized communities that we visited. This helped me get to know people from so many different backgrounds and so many groups of people that I had never even been aware of. It helped me see how privileged I am and how I should never take that for granted. This ignited a passion in me to find marginalized groups within our community and help them as well. (Respondent 319)

Several women and homosexual respondents shared how their study abroad experience empowered them to advocate for themselves as marginalized peoples:

After our time at LASP, I was able to advocate for ourself as both a woman and a homosexual in our work and with our family. I see now that there is room in the good news for me as well. (Respondent 205)

Additional actions that respondents related to their change in religious faith unfolded in the political sphere of their communities:

I think it is our religious duty to educate ourself about perspectives other than our own and to call out racism, sexism, classism, imperialism, etc. It is our religious duty to vote and to write letters to elected officials telling them to stand on the side of the people. I do not know what else I can do. (Respondent 38)

Respondents identified the donation of money and time through volunteerism as another community-based action that reflected their change in religious faith:

I support three missionary families who have moved to communities and are building grassroots movements and who put a value on building relationships with the communities and people they are serving and focus on economic development as well as sharing the gospel. I also sponsor a couple of kids through World Vision, focusing on holistic outreach, not just preaching. I also put together packs of food and supplies to give to homeless when I am driving around our own community. (Respondent 54)

In addition to community-focused actions, respondents also connected their change of religious faith to actions that impact their families.

Family decisions (43 respondents)

Respondents identified family decisions as another way they express their change in religious faith. Such decisions relate to spouse selection and child rearing. Several respondents commented on how their change in religious faith influenced spouse selection:

These changes have influenced the most important decision of our life - the decision to choose a spouse of a different 'religion.' Although not compatible in name, we are in spirit. (Respondent 23) 
Respondents also addressed the impact of this change on the way they raise children:

With our own children, I try to give them a world view that includes the third world by discussing the poor and having them involved with some of our giving decisions as a family. (Respondent 68)

While most respondents described actions that addressed communities or groups, some respondents spoke of actions that are more personal in nature.

Personal development (57 respondents)

Respondents expressed that their changes in religious faith allowed them to develop skills and awareness at a personal level. One respondent, for example, reported that she experienced a new awareness about her gender:

I realized that I as a woman actually had as much value as a man, and started going to therapy to heal the self-hatred I felt for no reason other than growing up thinking I wasn't as good as a man. (Respondent 228)

Other respondents shared about developing the skills of listening and practicing nonjudgment:

I am so much less judgmental than I used to be. It is easier to dialogue with people of other faiths and lifestyles and form relationships with them even if we disagree. (Respondent 200)

Research Question \#3: When LASP alumni perceive such a change in their religious faith, to which LASP components do they ascribe this change?

In understating responses to this question, it is important to note that only 49 of 382 respondents chose to identify a single LASP component as the most influential factor in this change event. The remaining 333 respondents perceived their changes in religious faith to have emerged from multiple components that worked together. Therefore, in our presentation of the results for research question \#3, we will address two groups of respondents: those who identified multiple components and those who identified a single component. Table 5 presents a comparative frequency count for both response groups as well as their combined total.

Table 5. LASP Components that Participants Identified as Most Influential in Changing Their Religious Faith

\begin{tabular}{llll}
\hline Component & $\begin{array}{l}\text { Respondents Who } \\
\text { Identified a Single } \\
\text { Component }\end{array}$ & $\begin{array}{l}\text { Respondents Who Identified } \\
\text { Multiple Components }\end{array}$ & $\begin{array}{l}\text { Total } \\
\text { Study trips }\end{array}$ \\
Relationships with host families & 14 & 163 & 177 \\
Lectures/speakers & 12 & 143 & 155 \\
Reading material & 8 & 144 & 152 \\
Discussion groups & 5 & 122 & 127 \\
Relationships with faculty & 2 & 74 & 76 \\
Relationships with other students & 4 & 49 & 53 \\
Viewing bible from new perspective & 2 & 47 & 49 \\
\hline
\end{tabular}

\section{Multiple components (333 respondents)}

Respondents in this group described study trips, relationships with host families, lectures, readings, and discussion groups as the components that most often worked together in this change event. Such responses suggest that this change was influenced by a combination of traditional learning experiences (lectures, readings and assignments), relationships (with host families, LASP faculty, and 
other students), and reflection (via discussion groups):

The readings began the thought process, opened our mind to the conceptual ideas that would later be made a personal matter of the heart via our relationships with host families and informal conversations. (Respondent 50)

Relationships, study trips, readings, process groups. Everything. It was incredibly wellbalanced to spark thoughts through the study, readings, and lectures, and then go out and see things in the world related to those ideas, have conversations with people in the middle of those issues in the world, and process the whole mixture of everything with our peers and professors who had a good idea of what we were experiencing. (Respondent 191)

While many students describe a balanced mix of factors, other respondents emphasized the value of certain components in this blend. Respondents often emphasized the value of discussion groups:

The process groups [discussion groups] helped me think through our shared experiences because it provided a soundboard in which we could share our thoughts together and think of things I wouldn't have considered or thought about on our own. (Respondent 169)

Some respondents emphasized their interactions with LASP faculty as a key ingredient in the mix of components they described:

It would be hard to say which component was the most influential. However, there were a few aspects of LASP that still stand out to me years later. The first of which is one of our professors, Laura. I remember her saying that she always sided with the marginalized, so I felt comfortable talking to her about our homosexuality. Through the conversations that followed, she recommended many books and authors to read to help me in that much needed healing. It was the first time I was shown that the Bible could be read differently. (Respondent 205)

Other respondents mentioned the important role that relationships with LASP peers had on their change in religious faith:

The very tight camaraderie that existed among the members of our semester (many of us are still in contact with each other) helped create that safe space in which to challenge the presuppositions we came with. (Respondent 153)

Respondents highlighted as well the way certain assignments required them to integrate formal learning with engagement of the local community:

Our assignments required us to ask interview questions - sometimes of our host families, sometimes of people on the street, or in a rural town, etc. If I hadn't been required to go out and interview people about very specific things (i.e., How do you feel about America? Do you feel like you have a voice in your own government? What do you think of our president? What do you think about God? Do you think God cares about you?), then I wouldn't have improved our Spanish OR gained varying perspectives about a lot of different issues. (Respondent 151)

While a most LASP alumni described multiple components that influenced their change of religious faith, a smaller group of respondents identified a single component as the most influential in this 
change.

Single component (49 respondents)

Similar to the results from those identifying multiple components, LASP alumni selecting a single component identified study trips, relationships with host families, lectures, and readings as the most influential components in this change event. Many respondents in this group stated that study trips created political, religious, and economic contrasts that facilitated a change in their religious faith:

Guatemala and Nicaragua revealed to me that some of the history that I had been taught as a child, was not just taught from an Evangelical-American perspective, but was purely false. People of our nationality and faith had committed atrocities. Though I had long before stopped idolizing our nation, these experiences taught me that the idolizing of our faith in our nation was equally foolish. The experience was both sobering and humbling. (Respondent 107)

Respondents in this group also identified relationships with host families as the key factor in their changes of religious faith. In respondents' views, living with a host family connected them to relationships that grounded their learning in tangible realities:

Our homestay with the Bri Bri people [indigenous community in Costa Rica]. I saw how reverently they interacted with nature, how generously they treated strangers, and how simple and peaceful their existence is, and then couldn't fathom how I once believed that their indigenous faith was evil and of Satan. This taught me that our concept of our Christian God being the One and Only God for all mankind had no footing - and that was I was experiencing with the Bri Bri actually confirmed the opposite - that the Bri Bri seemed to be worshipping the same god (one that embodies peace and generosity and goodness) and that perhaps there is only one god and he/she shows up in each religion differently. (Respondent 326)

\section{Document Mining of LASP Course Evaluations}

In our analysis of final course evaluations from 2008 through 2013 (see Appendix C), we encountered 258 qualitative comments. Of these 258 comments, 23 reflected students' perceptions that their study abroad experience influenced a change in their religious faith. Most of these comments were brief and fragmented expressions, such as "Our ideas about Christianity changed a lot" (Respondent from 2008) and "I only wanted to learn Spanish, but I learned so much more, I learned how to think critically, I learned and experienced how big and inclusive God is. Challenged every belief I've had and forced me to really think" (Respondent from 2009).

Although these 23 responses represented only $9 \%$ of the qualitative comments, they illuminated from a new angle LASP students' changes in religious faith. As the prompt under consideration reflects, students were not asked to comment on issues related to their religious faith. Therefore, the 23 responses that suggested LASP's influence on students' changes in religious faith supported the survey results.

\section{Discussion}

We organize our discussion of the results into four sections. First, we discuss the findings as they relate to Gardner's (2006) framework of mind change. Second, we illustrate the convergence of the 
results with Engle and Engle's (2003) study abroad classification system. Third, we connect the results to the practice of educational leaders. Finally, we identify areas of future research that emerge from the results.

\section{Gardner's (2006) Framework of Mind Change}

Gardner (2006) noted that each change of mind emerges from a unique blend of the levers of change. The degree of influence that each lever exercises varies by change event. The results of this study both confirm and expand Gardner's proposals on the drivers of mind change.

Consistent with Gardner's (2006) ideas, a majority of respondents (333/382) indicated that their changes in religious faith were influenced by a mix of factors during their study abroad experience. Students perceived their changes of religious faith to emerge from the way that formal learning experiences were brought to life through the concrete engagement of Latin American realities. Examining this event through Gardner's framework of mind change, LASP students perceived this change to be driven by the integration of the levers of reason and research (readings, lectures), representational redescriptions (experiencing course content in multiple forms through study trips, host families, and daily life), and resonance (through discussions and reflection).

An additional lever of change also emerged in the results, resistances. Gardner proposed (2006) that changes of mind are more to likely occur when resistances to change can be minimized and overcome by the weight of the other levers. Although survey prompts did not invite respondents to comment on the role that resistances played in this change, the influence of resistances was apparent in the data. In the case of this change event, respondents identified their home culture as a resistance to religious change. Furthermore, they noted that studying abroad distanced them from this resistance and allowed it to be overcome by the combination of other levers driving their religious faith in a new direction:

The LASP experience and core content gave me the space to question many things about our faith that I did not feel I was able to question in other more conservative environments. It allowed me to highlight issues of blind faith, hypocrisy, relationships between religion and politics, cultural and religious oppression and "missionization", etc. It provided a safe environment for tough questions to be asked, and ultimately led me to define and become comfortable with our current stance on religion. The experience was very instrumental in this regard. (Respondent 56)

Respondents also reported that their return to the United States reconnected them to the very resistances from which studying abroad had distanced them:

While I remained a Christian throughout the LASP experience and after I returned to the United States, I could no longer, with integrity, look through the same lenses that I had before LASP. This certainly conflicted with our faith community of origin, and sometimes felt irreconcilable to the lives they led inspired by their faith. It led to many hard conversations with parents, friends, theology professors, and a pastor who was a mentor to me. I didn't always feel welcome, desired to be seen and known in our new perspectives, and felt alone in our experience and new perspectives. (Respondent 74)

Thus, the results revealed that changes in the religious sphere often require difficult and ongoing 
engagement of resistances.

Clearly, Gardner's (2006) levers of change provide a tool for interpreting LASP students' changes in religious faith. Gardner's seven levers, however, fail to capture one element that respondents' identified as central to their changes of mind, relationships. Respondents frequently identified that relationships formed the connective tissue among the other levers at work in this change event:

Readings, assignments and lectures gave me insight in to different ways of thinking. Spending time with people in relationship is where the real changes occurred. These changes were mostly the result of conversations spurred on by the material we were studying at the time. (Respondent 94)

In fact, three of the components that respondents identified as the most influential in this change were relationships with host families, relationships with faculty, and relationships with other students. Combined, respondents' identified these relationship-centered components more frequently than any other theme in the data (257 respondents). Therefore, we propose that in the case of LASP students' changes in religious faith, relationships served as an additional, and central, lever of change.

\section{Engle and Engle's (2003) Study Abroad Classification System}

The results of this study support three of the characteristics that Engle and Engle (2003) associated with higher level programs: student housing with host families, frequent guided reflection on cultural experience, and ample provision for cultural interaction/experiential learning. Regarding student housing, the results provide vivid support for the value that students' placed on living with host families during their study abroad experience:

I would say that our relationships with our four host families was by far the most influential component of the trip. Everything that I experienced with them would have been completely lost had it been a study abroad program where we stayed in dorms. (Respondent 264)

Such perceptions about the influence that host families had on respondents' changes in religious faith support Engle and Engle's decision to associate this component with high level programs.

Regarding guided reflection, respondents' identified this characteristic as another key driver of their changes in religious faith:

LASP provided guidance and orientation to help understand the context and evaluate one's own values (or the way one expresses one's values) in light of this different context. So I think the main components are: quality staff that know how to challenge students and orient them; experiences that expose students to differing perspectives and/or values; intentional reflection [emphasis added] on these experiences and what they mean. (Respondent 197)

In a similar way, LASP alumni frequently identified the importance of direct cultural interaction and experiential learning as characteristics that galvanized their learning experience:

During our semester, we visited a 'sweatshop' in Nicaragua, and I saw them making a shirt from Target that I already own. In that same sweatshop, people called out to us and asked us to buy more Levi jeans, so that they could keep their jobs. That rocked our world. 
(Respondent 151)

Such findings support Engle and Engle's (2003) association of frequent guided reflection and ample provision for cultural interaction/experiential learning with higher level programs.

Although many results from our study support Engle and Engle's (2003) classification system, some findings challenge one characteristic of their system, academic work context. Engle and Engle proposed that higher level programs are often characterized by the direct enrollment of foreign students at a local university. The participants in our study, however, reported a high level of intercultural engagement while participating in a hybrid program, LASP. In the case of LASP, the program structure captures the cultural features of direct enrollment by foregrounding Latin American lecturers in coursework, while creating an independent schedule (not tied to university calendars) that allows for regular study trips to neighboring countries. As respondents' comments indicated, both lectures and study trips were central drivers in their change in religious faith. Thus, the results of our study invite critical reflection on whether direct enrollment represents a deeper engagement of the host culture than hybrid models.

In addition to challenging Engle and Engle's (2003) views on the superiority of direct enrollment programs, the results of our study suggest that their model should place more emphasis on the nature of formal assignments that students complete during study abroad. For example, numerous respondents in our study identified the interview component of their research assignments as a factor in this change event:

The assignments that put us face to face with people in interview experiences had the most impact on me. This includes: interviewing our Nicaraguan host family about the impact of politics on their faith and family, talking to the homeless and the women in Costa Rica who were formerly prostitutes, and time spent talking to people from the Kuna Yala tribe and the Bri tribe about their creation and origin stories and tracing how indigenous religions synchronized with Christianity. (Respondent 88)

Thus, the results of our study encourage additional reflection on the role that assignment structure can have in students' learning experiences abroad. Such findings suggest that assignments should emphasize students' engagement of primary sources that are unavailable to them on a U.S. campus.

\section{Practice of Educational Leaders}

The results of our study highlight several ways that educational leaders can improve their work related to study abroad. We discuss these recommendations for practice in the context of two groups of educational leaders: field-based study abroad professionals and campus-based study abroad professionals. The results of this study suggest that educational leaders can benefit from critically considering the following proposals.

Field-based study abroad professionals.

1. Prioritize home stays over other student housing options. The results of this study indicate that host families play a central role in the transformational learning of students during study abroad.

2. Increase the prevalence of guided reflection in coursework and extracurricular 
programming. The results of this study identify intentional reflection as a key ingredient in meaningful student learning while abroad. Experiential learning alone is insufficient.

3. Prioritize the perspectives of the host community in coursework and learning experiences. The results of this study indicate that the contrast between students' views and those of hosts sparked an important shift in students' development.

4. Integrate community-based research with written assignments. Respondents reported, for example, that being required to interview members of their host community added a powerful dimension to their learning.

5. Consider modifying the structure of direct enrollment programs. The results of this study show that U.S. university students benefit from hybrid study abroad models that allow for guided regional study trips and careful intervention from faculty who understand U.S. and host cultures.

Campus-based study abroad professionals.

1. Use Engle and Engle's (2003) study abroad classification system to assess the programs that universities support. Through this evaluation, consider disapproving experiences that do not meet the characteristics of the higher level programs.

2. Engage faculty who lead short-term study abroad programs. Such engagement should encourage faculty to integrate home stays into short-term experiences, invite experts from the host community to lecture during coursework, and create assignments that require student engagement of the host community.

3. Prioritize re-entry programming for students returning from study abroad. Findings from this study indicate that many students experience difficult transitions when returning to the U.S. following their study abroad experience.

\section{Recommendations for Future Research}

In a broad sense, this study confirms the usefulness of Gardner's (2006) framework of mind change as a tool to interpret change events and processes. Additional research that uses Gardner's framework will add to our understanding of its ability to explain mind change in different spheres and contexts. In a similar spirit, the results of our study confirm the effectiveness of Engle and Engle's (2003) study abroad classification system as a tool to precisely define and evaluate study abroad programming. Additional research on how this tool converges with student learning would strengthen the literature.

Additional research to explore the impact of specific study abroad components on student learning would add to current understanding of what makes education abroad transformational. Such research, of course, should examine study abroad outcomes beyond that of students' religiosity.

One dimension of this study included the exploration of how respondents' perceived this change to influence actions in their communities and the world. Additional research to explore how study abroad relates to students' actions would also strengthen this body of literature. Although much research illustrates study abroad's impact on diverse learning outcomes, research rarely examines how 
such outcomes inform students' future behaviors.

Finally, respondents in our study frequently articulated the importance of relationships they developed with people in their host communities. Unfortunately, study abroad research largely ignores the perspectives of host communities. Particularly when examining students' development of intercultural competencies, it would be relevant to include perspectives from hosts on how such student learning unfolds.

\section{References}

Black, H. T., \& Duhon, D. L. (2006). Assessing the impact of business study abroad programs on cultural awareness and personal development. The Journal of Education for Business, 81(3), 140 144.

Creswell, J. W. (2012). Qualitative inquiry and research design: Choosing among five approaches. Los Angeles: Sage Publishing

Council for Christian Colleges \& Universities (2015). Our mission. Retrieved March 1, 2015 from www.cccu.org

Deardorff, D. K. (2006). Identification and assessment of intercultural competence as a student outcome of internationalization. Journal of studies in international education, 10(3), 241-266.

de Witt, H. (2009). Internationalization of higher education in the United States of America and Europe. Chestnut Hill: Boston College.

Dwyer, M. \& Peters, C. (2004). The benefits of study abroad. Transitions abroad, 37(5), 56-58.

Egron-Polak, E. (2012). Internationalization of Higher Education: A Few Global Trends and Regional Perspectives. In C. Ennew \& D. Greenaway (Eds.), The Globalization of Higher Education (pp. 57-69). New York: Palgrave Macmillan

Engle, L., \& Engle, J. (2003). Study abroad levels: Toward a classification of program types. Frontiers: The Interdisciplinary Journal of Study Abroad, 9, 1-10.

Fowler, J. (1981). Stages of faith: The psychology of human development and the quest for meaning. San Francisco: Harper \& Row Publishing

Freed, B. (Ed.). (1995). Second language acquisition in a study abroad context (Vol. 9). Philadelphia: John Benjamins Publishing Company.

Gardner, H. (2006). Changing minds: The art and science of changing our own and other people's minds. Boston: Harvard Business School Press

Golay, P.A. (2006). The effects of study abroad on the development of global-mindedness among students enrolled in international programs at Florida State University. Dissertation Abstracts International, 67 (08).

Institute of International Education (2014). Open doors report: 2014. Retrieved March 1, 2015, http://www.iie.org/Research-and-Publications/Open-Doors/Data/US-Study-Abroad

Kehl, K. (2006). Differences in self-efficacy and global mindedness between short-term and semesterlong study abroad participants at selected Christian universities. Dissertation Abstracts International, $66(10), 3525 \mathrm{~A}$.

Kinginger, C. (2004). Alice doesn't live here anymore: Foreign language learning and identity reconstruction. In A. Pavlenko \& A. Blackledge (Eds.), Negotiation of identities in multilingual contexts (pp. 219-242), Clevedon: Multilingual Matters.

McMurtrie, B. (2009). Study abroad programs diversify as their popularity grows. The Chronicle of Higher Education, 56(23), A24.

Patterson, J. A. (2001). Shining lights: A history of the Council for Christian Colleges \& Universities. Grand Rapids: Baker Academic. 
Patton, M. (2002). Qualitative research \& evaluation methods. Thousand Oaks: Sage Publications. Qualtrics (2015). The world's leading enterprise survey platform. Retrieved August 22, 2015 from www.qualtrics.com

Railsback, G. (2006). Faith commitment of born-again students at secular and Evangelical colleges. Journal of Research on Christian Education, 15(1), 39-60.

Smith, C., \& Snell, P. (2009). Souls in transition: The religious and spiritual lives of emerging adults. New York: Oxford University Press.

Williams, T. R. (2005). Exploring the impact of study abroad on students' intercultural communication skills: Adaptability and sensitivity. Journal of Studies in International Education, 9(4), 356-371. 


\section{Appendix A. Survey of LASP Alumni}

\section{Consent Form}

Mind Change as Related to Study Abroad:

Students' Perceptions about Changes in Their Religious Faith at the Latin American Studies Program

You are invited to participate in a study about the impact of study abroad programming on students. You were selected as a possible participant because you studied abroad with the Latin American Studies Program (LASP). I ask that you read this form and ask any questions before agreeing to be in the study.

This study is being conducted by Trevor Poag at Lehigh University's College of Education, under the direction of Dr. Jill Sperandio at Lehigh University's College of Education.

The purpose of this study is to explore students' perceptions of how their study abroad experience at the LASP influenced a change of mind about their religious faith. In addition, the study aims to identify which LASP program components most powerfully influenced this change event.

If you agree to be in this study, I ask you to invest a few minutes in the completion of the survey below.

Possible risks for participants in this study include experiencing emotional discomfort while completing the survey, which invites you to describe changes to your religious faith. Your completion of the survey is voluntary. Should you experience any emotional discomfort while completing the survey, you may choose to stop participating at any time.

The benefits to participants in this study include having the opportunity to reflect on how your study abroad experience with LASP impacted you. In addition, your participation contributes to ongoing knowledge about how study abroad influences students. Such knowledge will improve the design and implementation of future study abroad programming.

You will not receive compensation for your participation in this study.

Confidentiality of the data in this study is of highest importance to the researcher. In fact, your completion of the survey is anonymous. The researcher will have no record of which LASP participants choose to participate in this study. Thus, in any published report of this study, it will be impossible to identify a participant.

Participation in this study is voluntary. Your decision whether or not to participate will not affect your current or future relations with the researcher or the institutions he represents. If you decide to participate, you are free to not answer any question or withdraw at any time without affecting such relationships.

If you have questions about this study, do not contact the researcher (this would threaten the anonymity of the study). Instead, please contact Susan E. Disidore at (610)758-3020 (email: sus5@lehigh.edu) or Troy Boni at (610)758-2985 (email: tdb308@lehigh.edu) of Lehigh University’s Office of Research and Sponsored Programs. All reports or correspondence will be kept confidential.

Your decision to complete the survey is confirmation of your consent to participate in this study.

\section{Survey of LASP Alumni}

Thank you for investing a few minutes in the completion of this survey, which explores how your religious faith was influenced by your study abroad experience at the Latin American Studies Program (LASP). For the purpose of this survey, religious faith describes one's efforts to know, value, and construct meaning in the world.

Please note the semester and year that you attended LASP:

Was your LASP experience influential in changing your religious faith in any way? Yes / No

If you answered "no" to question \#1, you are finished with this survey. Please submit the survey. If you answered "yes" to question \#1, please complete the rest of the survey.

Briefly describe the key changes in your religious faith that you feel are related to your LASP experience. 
How do such changes in your religious faith inform your actions in your community and the world?

Which LASP components (readings, assignments, lectures, relationships with host families, informal conversations, process groups, study trips, some mix of these, or other factors) most influenced the changes and actions you described in questions \#2 and \#3?

Thank you for investing your time in the completion of this survey. Your perspectives provide useful data for this study, which aims to improve future study abroad programming. 


\section{Appendix B. LASP Final Course Evaluation}

Name (optional)

Council for Christian Colleges and Universities

Latin American Studies Program

Final Evaluation

Fall XXXX

\section{A. REENTRY RETREAT}

Miami (appropriate location for reentry?)

thumbs down 12345 thumbs up

Hotel. .inappropriate 12345 appropriate

Student talent show waste of time 12345 a must

Workshop. worthless 12345 valuable

Overall assessment of reentry activities worthless 12345 valuable

\section{B. OVERALL LATIN AMERICAN STUDIES PROGRAM}

The value of studying in Latin America. .very little 12345 priceless

On LASP I learned about Latin America. hardly anything 12345 very much

On LASP I learned about ourself. .hardly anything 12345 very much

Overall assessment of LASP awful 12345 excellent

\section{SURVEY QUESTIONS}

How did you learn about LASP?

Did you seriously consider any other off-campus program for this semester or any other semester? Where?

Why did you choose to participate in this student program?

Additional comments about your semester at LASP: 